\title{
ANALYSIS BASED ON THE INDUSTRY OF THE HOTEL SECTOR IN MEXICO: POSADAS CASE
}

\author{
José G. Vargas-Hernández ${ }^{1}$ \\ Lic. Kurt Tonatiuh Winkler Benítez ${ }^{2}$
}

DOI: https://doi.org/10.31410/tmt.2019.559

\begin{abstract}
The objective of this brief general market analysis is to determine with the VRIO framework how the Posadas group has managed to maintain itself in the Mexican lodging market. The aim is to understand how in the current panorama of tourism are the main challenges of the Posadas group. The main question that generated this analysis was: Is Grupo Posadas the current leader in the hospitality sector in Mexico? The hypothesis is that the strategies implemented by Grupo Posadas have allowed it to remain in the lodging sector; however, the current elements are not strong enough to be the market leader. So, combining the analysis elements of the market and the VRIO, results were obtained that pointed to Posadas shares, the leadership with IHG Hotels which begins to generate a more marked oligopolistic competition in the field of tourism.
\end{abstract}

Keywords: Tourism, hospitality, industry.

\section{INTRODUCTION}

ccording to the information of Posadas Group, the hotel company was born in 1967, when Mr. Gastón Azcárraga founded Promotora Mexicana de Hoteles, S.A. with the purpose of participating in the lodging sector with the construction and operation of a hotel in the Federal District called Fiesta Palace, now known as Fiesta Americana Reforma. Two years later, it has a strategic alliance and partnership with American Hotels, thus forming the Operadora Mexicana de Hoteles. It is important to mention that the most emblematic franchise of Posadas is Fiesta Americana since the first hotel of this franchise was opened in 1979 in Puerto Vallarta. From then on, a new facet began in 1982. When Promotora Mexicana de Hoteles, S.A. and Gastón Azcárraga Tamayo bought $50 \%$ of the capital stock of Posadas de México.

Now, the birth of Posadas as such occurs in 1969 by Pratt Hotel Corporation of American origin for the purpose of operating and managing the Holiday Inn franchises in Mexico. In the year of 1990 Promotora Mexicana de Hoteles, takes the initiative to buy $50 \%$ of the shares of Posadas and with the acquisition allowed the emergence of the largest and oldest company in Mexico for modern times, with the operation of 13 hotels. One of the main advantages at the moment of having this acquisition and as a positioning was the management of the Holiday Inn hotels and the operation of the Fiesta Americana hotels.

The final transformation of the company occurred in 1992 when Promotora Mexicana de Hoteles changed its name to the current Grupo Posadas. That same year, the company began trading on the Mexican Stock Exchange (BMV). From then on Posadas began to attack the different

\footnotetext{
1 Departamento de Administración Centro Universitario de Ciencias Económico-Administrativas. Universidad de Guadalajara, Periférico Norte 799 Edif. G201-7, Núcleo Universitario los Belenes, Zapopan, Jalisco, 45100, México

2 Kurt Tonatiuh Winkler Benítez, Maestría en Negocios y Estudios Económicos, Centro Universitario de Ciencias Económico Administrativas, Universidad de Guadalajara
} 
segments of the tourism market starting in 1993 with business tourism with the opening of the first Fiesta Inn. In 1998 the company had its first elements of international expansion with the acquisition of the Caesar Park chain along with the rights to use the brand in Latin America, thanks to this purchase, in 2001 the first Caesar Business was inaugurated in Sao Paulo, Brazil.

In the 80's, Grupo Posadas realized that managing third-party hotels exported more reservations than it obtained. This was very common because the industry in these years was going through a period of saturation in the tourism sector. Posadas decided to focus then on the development of its own brands while continuing with the operation of the Holiday Inn franchise in the busiest destinations.

In 1992, the Company changed its name to Promotora Mexicana de Hoteles, S.A. of C.V. to the current Grupo Posadas, S.A. of C.V. In March of that same year, the Company was listed on the Mexican Stock Exchange. In 1993 it began to attack the business traveler segment with the opening of the first Fiesta Inn in city destinations. In 1998 the Company began its expansion in South America through the acquisition of the Caesar Park chain, together with the rights to the brand in Latin America. In 2001, the Company opened its first Caesar Business hotel in Sao Paulo, Brazil. Currently, in 2019, Posadas group has a positioning of 176 hotels and 27,573 rooms nationwide (Grupo Posadas, 2019).

\section{BACKGROUND AND GLOBAL PANORAMA}

The hotel sector had a strong development after the First World War, which is a product of the economic and technological elements that have occurred in the history of mankind since that period. Its boom as already mentioned was highlighted after the First World War. With the consequences of this phenomenon in the course of the second half of the 20th century, a constant increase in international tourist flows skyrocketed, that is, there were more determining factors that motivated the increase in hotel demand worldwide and this way the lodging industry had more development (Figure 1).

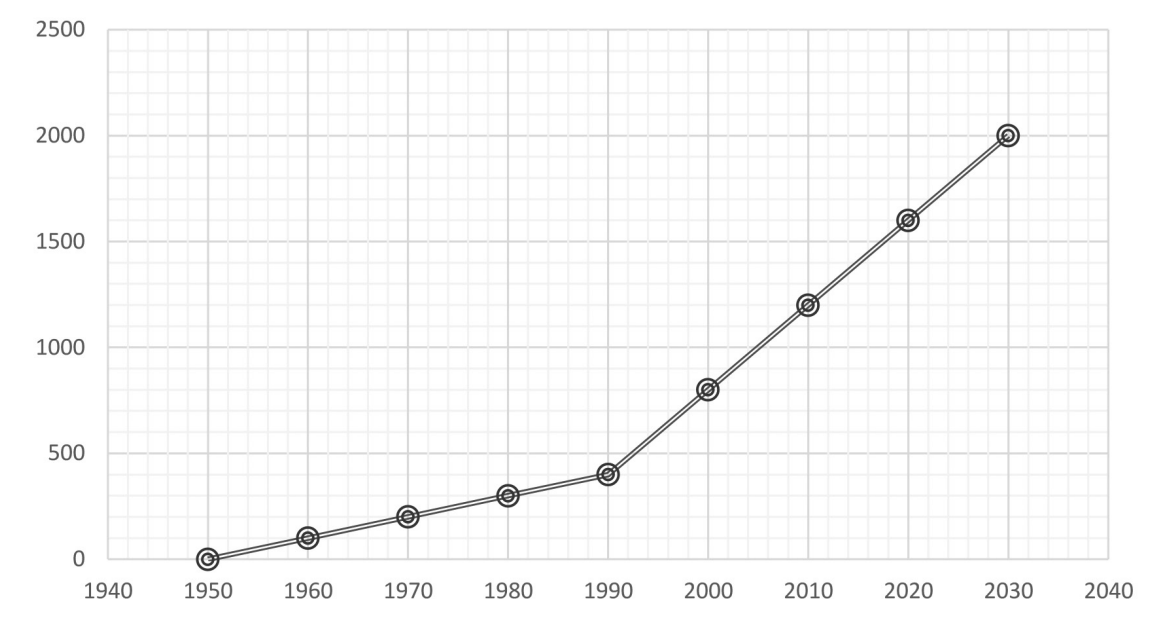

Figure 1: Travel growth

Source: Growth of international travel for tourism purposes since 1950, according to the World Tourism Organization (UNWTO).

As an economic activity, the so-called ,industry without chimneys" maintains a strong link with hospitality in its different modalities, be it family, individual, business and in different 
ranges of services that can be considered as ,additional”. Tourism is often referred to as the „industry without chimneys”, because it does not pollute. Although this is not entirely true, there is a great debate about the pollution of tourism that has a direct or indirect impact on the construction of the tourist infrastructure or the tourist destination.

The phenomenon ceased to be a privilege of a few rich families in the seventeenth and eighteenth centuries, to give way to mass tourism from the boom of the fifties of the twentieth century, with the development of new technologies in connectivity and logistics (media of transport) that have made tourism and hospitality of the world's most present industries.

Table 1: Main tourist destinations in the world by foreign currency income

\begin{tabular}{|c|c|l|c|c|}
\hline \multicolumn{2}{|c|}{ Classification } & \multirow{2}{*}{ Country } & $\mathbf{2 0 1 6}$ & $\mathbf{2 0 1 7}$ \\
\cline { 4 - 5 } $\mathbf{2 0 1 6}$ & $\mathbf{2 0 1 7}$ & & 206.9 & 210.7 \\
\hline 1 & 1 & United States & 60.5 & 68.1 \\
\hline 2 & 2 & Spain & 54.5 & 60.7 \\
\hline 3 & 3 & France & 48.8 & 57.5 \\
\hline 4 & 4 & Thailand & 47.9 & 51.2 \\
\hline 5 & 5 & United Kingdom & 40.2 & 44.2 \\
\hline 7 & 6 & Italy & 37 & 41.7 \\
\hline 9 & 7 & Australia & 37.5 & 39.8 \\
\hline 8 & 8 & Germany & 30.4 & 35.6 \\
\hline 12 & 9 & Macao (China) & 30.7 & 34.1 \\
\hline 11 & 10 & Japan & 32.8 & 33.3 \\
\hline 10 & 11 & Hong Kong (China) & 44.4 & 32.6 \\
\hline 6 & 12 & China & 22.4 & 27.4 \\
\hline 13 & 13 & India & 18.7 & 22.5 \\
\hline 18 & 14 & Turkey & 19.6 & 21.3 \\
\hline 14 & 15 & Mexico & 1246 & 1340 \\
\hline
\end{tabular}

Source: Monitoreo Hotelero DATATUR 2018

Taking into account the above, it is expected that there will be greater accessibility in the following years for the hosting areas such as logistics, with which the trips and the phenomenon will have an exponential growth. In comparatives Mexico in tourism is among the top 15 in terms of foreign exchange earnings and in the top 10 of the most visited destinations in the world, it can be considered Mexico as a stable country in terms of tourism up to its most recent published global statistics (tables 1 and 2) (SECTUR, 2018).

The document „OMT Panorama of International Tourism 2017”, which is the most up-to-date document of the tourism ranking so far, indicates that in the arrival section of tourists Mexico is in sixth place with 39.3 million foreign tourists. With a scale from the eighth place to the sixth place in the international table. These results published by the World Tourism Organization (WTO) show a „favorable outlook” as some members who have faced security challenges in recent years have been sustained by the existing demand for travel to these destinations.

The other fundamental part is the entry of foreign currency, i.e. the amount of money spent in the country visited, there was a decrease from one position from 2016 to 2015 down from 14 to 15th. This indicates that, although the country is of the most visited at the international level does not have enough attraction to generate a greater demand in consumption for the tourist. 
Table 2: Main tourist destinations in the world by arrival of tourists

\begin{tabular}{|c|c|l|c|c|}
\hline \multicolumn{2}{|c|}{ Classification } & \multirow{2}{*}{ Country } & $\mathbf{2 0 1 6}$ & $\mathbf{2 0 1 7}$ \\
\cline { 4 - 5 } $\mathbf{2 0 1 6}$ & $\mathbf{2 0 1 7}$ & & 82.7 & 86.9 \\
\hline 1 & 1 & France & 75.3 & 81.9 \\
\hline 3 & 2 & Spain & 76.4 & 76.9 \\
\hline 2 & 3 & United States & 59.3 & 60.7 \\
\hline 4 & 4 & China & 52.4 & 58.3 \\
\hline 5 & 5 & Italy & 35.1 & 39.3 \\
\hline 8 & 6 & México & 35.8 & 37.7 \\
\hline 6 & 7 & United Kingdom & 30.3 & 37.6 \\
\hline 10 & 8 & Turkey & 35.6 & 37.5 \\
\hline 7 & 9 & Germany & 32.5 & 35.4 \\
\hline 9 & 10 & Thailand & 28.1 & 29.5 \\
\hline 11 & 11 & Austria & 24 & 28.7 \\
\hline 16 & 12 & Japan & 26.6 & 27.9 \\
\hline 13 & 13 & Hong Kong (China) & 24.8 & 27.2 \\
\hline 14 & 14 & Greece & 26.8 & 25.9 \\
\hline 12 & 15 & Malaysia & 1240 & 1326 \\
\hline
\end{tabular}

Source: Monitoreo Hotelero DATATUR, 2018

Some elements already confirmed for the international tourism panorama 2018 indicate that there will be an assured decrease of a place since Turkey had an increase of $18 \%$ in its tourist attraction and will have displaced Mexico to position number 7. Another important factor is, according to the head of the Ministry of Tourism (SECTUR) Miguel Torruco, that the figures from the United Kingdom and Germany have not yet been taken into account due to the lack of consolidation, which could condition the country to drop another two places (Expansión, 2019).

\section{NATIONAL PANORAMA}

Currently the tourism landscape is at constant levels since 2015 with a trend in an occupancy rate of 59.6 to 60.9 in 2018. The expectation for 2019 is to break the historical record of the year 2017 where it took place the highest percentage of occupation at the national level (SECTUR, 2018). However, as figure 2 shows with the data for 2018, the result was not as expected as, with the alerts to the tourist in the United States about not traveling to some Mexican states due to insecurity factors, environmental elements such as Sargasso and the uncertainty of the monetary value of the peso braked arrivals of international travelers, which, as already mentioned, affected the levels of the ranking without adding the data not confirmed by some countries.

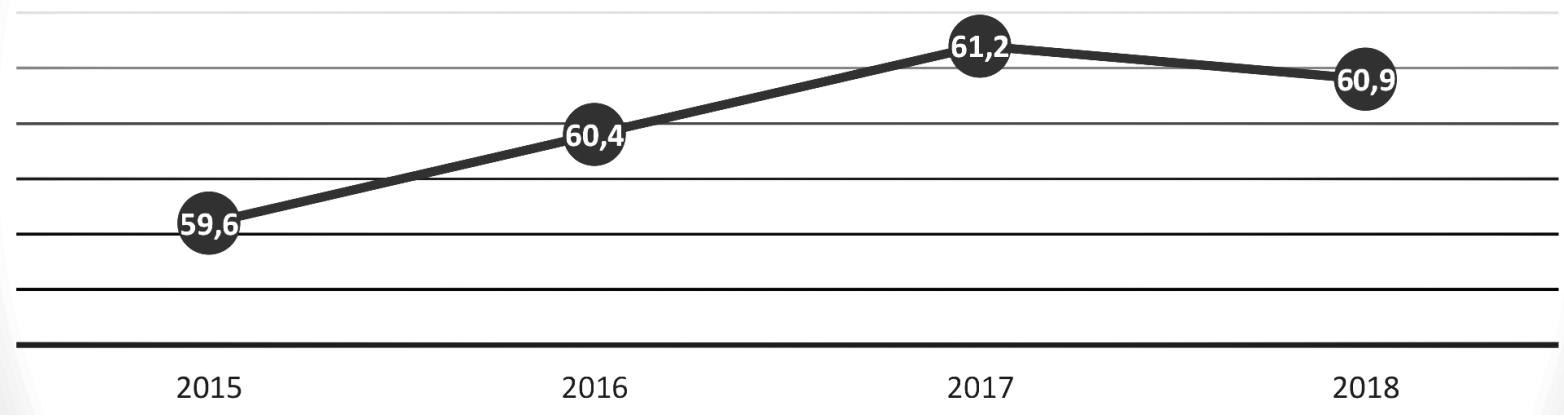

Figure 2: Percentage of the occupation nationwide

Source: (SECTUR, 2018). 
Now, in the percentage of current hotel occupancy talking about the year 2019, in comparison with the data of the month of March of the year 2017 and 2018, it is possible to have a forecast, that is to say: only the months of January, February and March have been measured, which in their accumulated and in comparison with the same months of the past years indicate a decrease in the tourist activity of $1.2 \%$. It is necessary to mention that the occupation percentage does not necessarily reflect how important a destination could be in the influx of tourists, but rather that it reflects the saturation of the destination according to the tourist offer that exists in it (hotels, rooms available). That is why it is an indicator that shows us the importance of the investments that are made in the tourist poles (DATATUR, 2019).

Table 3: Percentage of Occupation (March).

\begin{tabular}{|c|c|}
\hline Year & Total \\
\hline 2017 & 64.5 \\
\hline 2018 & 65.7 \\
\hline 2019 & 64.5 \\
\hline
\end{tabular}

Source: Hotel monitoring program „DATATUR” March 2019

These elements of low tourist activity of 2019 with the comparison of the previous year can be linked to the little diffusion that has been done internationally in the tourism market and the competitive market that exists in Latin America. In an interview with Aristegui Alejandro Zozaya, director of the conglomerate Apple Leisure Group, Apple Vacations and the AMResorts chain, one of the strongest allies in the tourism sector in our country as the most important market that leads the country is the North American high-end, such as high-level weddings and honeymoons, since that represents $62 \%$ of tourism to Mexico by the group.

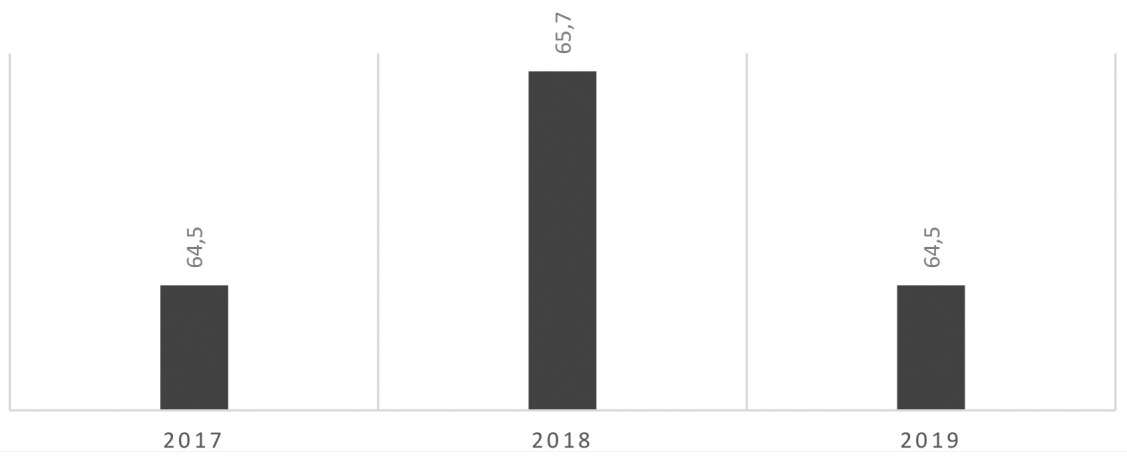

Figure 3. Comparative occupation rate (March)

Source: Hotel monitoring program „DATATUR” March 2019

In an interview it is detailed that what is happening with tourism in Mexico is not the result of a fall of the international market but a decision of the tourist to go to other destinations that are not Mexico (Aristegui News, 2019). That is the importance of the promotion, said in an interview and explained that when the pleasure tourist is about to make a decision, advertising is the main conduit that generates taste or preference and in the case of tourism (Aristegui News, 2019).

Taking into account the above and analyzing hotel occupancy data at the state level, it can be seen the hotel market as a more accurate panorama to make a comparison of the 10 most competitive states that Mexico has. It is important to take into account as already mentioned before, that a percentage of occupation does not necessarily lie in the fact that the state has more ,existing” or ,available” quarters, if there is enough affluence for all the rooms to be occupied, so it is 
important that this be done specification to understand why a percentage of occupation directly affects the competitiveness of a destination and the importance as an indicator for future investors in these destinations as well as a possible trend of the expected percentage of occupation.

Table 4: Comparison of rooms at national level 2018

Rooms 2018

$\begin{array}{lccccc}\text { State } & \text { Existents } & \text { Average } & \text { Available } & \text { Occupancy } & \begin{array}{c}\text { Percentage of } \\ \text { occupancy }\end{array} \\ \text { Quintana Roo } & 100,986 & 91,489 & 33,393,485 & 26,369,581 & 78.97 \% \\ \text { Jalisco } & 75,422 & 45,099 & 16,461,135 & 12,346,827 & 75.01 \% \\ \text { Ciudad de } & 21,912 & 41,993 & 15,327,445 & 11,007,033 & 71.81 \% \\ \text { México } & 34,745 & 19,926 & 7,272,990 & 5,145,101 & 70.74 \% \\ \text { Nayarit } & 24,277 & 20,771 & 7,581,462 & 4,785,392 & 63.12 \% \\ \text { Baja California } & 11,829 & 4,317,585 & 2,719,076 & 62.98 \% \\ \text { Sur } & 26,818 & 4,260 & 1,554,762 & 966,104 & 62.14 \% \\ \text { Tamaulipas } & 6,909 & 8,657 & 3,159,805 & 1,915,721 & 60.63 \% \\ \text { Aguascalientes } & 13,076 & 14,108 & 5,149,420 & 3,017,403 & 58.60 \% \\ \text { Yucatán } & 20,942 & 14,365 & 5,243,225 & 3,049,344 & 58.16 \% \\ \text { Sinaloa } & 18,923 & & \end{array}$

Source: Own elaboration with data from DATATUR 2018

These 10 destinations are the highest in hotel occupancy taking into account that it has been used only from the database of DATATUR hotels of 3 stars and up since the activity of the main hotel chains that are located in Mexico have their establishments positioned in these sectors. This is with the purpose of generating an analysis of the Posadas group and its commercial strategy, as well as its competitors. The percentages of occupation more than the arrivals of national or international tourists shows the capacity of the destination and the ,profitable" that it can be to invest in hotel matter in the state / area or type of destination depending on the variables used; as can be seen in past graphs of the destinations it can be cataloged in different ways depending on the specialization or type of study objective in hotels accounted for.

\section{CURRENT SITUATION IN THE LODGING}

There are 13 face-to-face chains in the lodging market in Mexico, of which those with a higher level of hotels are: Posadas, IHG, Marriot, Hilton, Wyndham. Each one has different categories of hotels with different rooms and with different themes. In this way, it can be seen what is the value proposition of each of the hotels and to which market segment they are related at a national level. Posadas' firm competes with the following companies:

It is also important to mention that the table reflects in general the number of hotels and rooms per corporate and does not make a distinction between its different chains or franchises that generate the main differentiator between each one in the market; in general terms of the market of 3, 4 and 5 stars, these are the corporates which are located in Mexico. Taking into account the above, it can be affirmed that Posadas Group maintains the leadership in terms of hotels and rooms, which gives it the highest percentage of the market; however, its percentage is very close to that of the strongest chain globally with a difference minimal. 
Table 5: Comparison of the chains

\begin{tabular}{|l|c|c|c|c|}
\hline Chain & Hotels & Rooms & Rooms percentage & Hotel percentage \\
\hline Posadas & 176 & 27573 & $23 \%$ & $26 \%$ \\
\hline IHG & 139 & 21611 & $18 \%$ & $21 \%$ \\
Marriott & 76 & 7200 & $6 \%$ & $11 \%$ \\
\hline Hilton & 55 & 7600 & $6 \%$ & $8 \%$ \\
Wyndham & 50 & 6200 & $5 \%$ & $7 \%$ \\
Grupo Real Turismo & 41 & 6885 & $6 \%$ & $6 \%$ \\
Misión & 37 & 3650 & $3 \%$ & $6 \%$ \\
Vidanta & 25 & 7000 & $6 \%$ & $4 \%$ \\
Riu & 17 & 9200 & $8 \%$ & $3 \%$ \\
NH & 16 & 5200 & $4 \%$ & $2 \%$ \\
Hyatt & 16 & 4600 & $4 \%$ & $2 \%$ \\
Palace Resorts & 12 & 6000 & $5 \%$ & $2 \%$ \\
Melia & 12 & 5400 & $5 \%$ & $2 \%$ \\
Totals & 672 & 118119 & $100 \%$ & $100 \%$ \\
\hline
\end{tabular}

Source: Own elaboration with information of the corporate pages of the hotels 2019

\section{MARKET STRUCTURE AND CONCENTRATION INDEX}

Taking into account the above, it can be assumed that the lodging sector in Mexico is a monopolistic competition. However, this may not be true. To understand more deeply how the market is, it is necessary to corroborate this information, which can be done with the indices of concentration which are in the annexes. Then, the results of the two concentration models that were obtained for the purposes of this analysis are added (See Annexes).

For the first analysis in the concentration index, the sum of the four companies was taken as a measure. The existing rank of concentration has a scale from 0 to 100 where 0 represents the case of perfect competition and 100 represents a monopolistic concentration. This is the main measure used to evaluate the structure of the market. The concentration coefficient is the sum of the 4 largest companies and the total sum which gives a result of $66.36 \%$. According to Parkin, over $60 \%$ indicates a very concentrated market dominated by few companies in an oligopoly (Parkin, 2010) (Annex 1).

In order to corroborate the market concentration also for the analysis of this sector, the Herfindahl-Hirschman index (HHI) is used, which indicates that the lower the number, the more perfect the competition and the larger the market the more concentrated and begins to behave in a monopolistic manner. In the case of hospitality, the index has a value of 1470 which, according to the theory, puts us in a "moderately competitive" area since the interval for this definition is between 1000 and 1800 (Parkin, 2010) (Annex 2).

Therefore, it can be mentioned that in this confirmation of indexes there is an oligopoly. In it, the participants are few and the market price is influenced at the same time as its competitors, that is, the profit of the participating companies is not only a function of their level of production, but also according to the production of the rest of the companies. And in particular in this sector, it is a differentiated oligopoly, that is, we have the same product, but different characteristics. This is where this same differentiation makes the oligopoly have characteristics similar to monopolistic competition, however the assumptions are different. 


\section{MARKET DIFFERENTIATION}

The differentiation of Posadas Group stands out for its different elements in the value proposals in each of its hotel franchises. Grupo Posadas has 7 hotel franchises with different market segments for each of them, which can be seen on their website.

1. Live Aqua: Live Aqua are hotels established for a segment of clients looking for ,informal" but with luxury elements. They have simple but very elegant establishments and the first level service in kitchen, spa, lounge. It is the „highest” of the hotels Posadas has in its range of segmentation.

2. Fiesta Americana: The Fiesta Americana hotels are the most emblematic of the chain. They are five star and have luxury services as standard.

3. Fiesta Americana Grand: The Grand Hotels are a derivative of Fiesta Americana which offer a sense of „exclusivity” and „business"; it can be mentioned that they are the VIP of the Fiesta Americana. They are those that have more percentage of entry with the „Awards" the loyalty program of Fiesta Americana.

4. D. Fiesta Inn: Fiesta Inn enters the „business” segment of Posadas which focuses on short stays and for work reasons, are suitable with elements to work in the room comfortably and with a series of services aimed at necessary to operate an office.

5. One Hotels: The One hotels are the second best brand positioned in the Posadas group market since they have 49 hotels nationwide as opposed to the 75 Fiesta Inn. The main market sector they are specialized in is low cost and short stays for work reasons. This mix follows the parameters of Fiesta Inn but with cheaper elements.

6. The Explorean: The Explorean offers luxurious and top-quality stays in natural and cultural sites for its guests to enjoy a feeling of relaxation and complete disconnection.

The value proposition of each of the brands explained competes in the market against similar elements and therefore substitutes, that is, goods or services that satisfy the need to a satisfactory utility for the agent and the price is the determinant for the election of the clients. (Posadas Group, 2019). Taking into account the VRIO matrix, these are the main elements of the Posadas group in their value proposition.

Table 6: VRIO analysis comparison

\begin{tabular}{|l|c|c|c|l|}
\hline VRIO Analysis & Posadas & IHG & Marriot & Key questions \\
\hline Value & No & No & No & Is it valuable? \\
\hline Rarity & No & No & No & Is it hard to find? \\
\hline Inimitability & No & No & No & Is it difficult to copy? \\
\hline Organization & Sí & Sí & Sí & Is there an organization to exploit the resource? \\
\hline
\end{tabular}

Source: Own elaboration.

The hotel sector is undoubtedly an intangible service; however, it is important to mention that it is a perfect substitute, that is, unless the „rewards" program of the different competences has already marked a preference or an alliance is chosen by the factor price and service and not so much for the intangible elements that are considered ,plus”. That is why Posadas' positioning analysis focuses more on the number of rooms and hotels that it has nationally, than its VRIO. Taking this into account, the value proposition of each of the brands and the market segment to which they are directed generate the following panorama. 
Table 7: Posadas Group

\begin{tabular}{|c|l|l|c|c|}
\hline Scale ID & Chain Scale & Affiliation Name & México & Rooms \\
\hline 2 & Upper Upscale Chains & Live Aqua & 5 & 793 \\
\hline 3 & Upscale Chains & Fiesta Americana/ Grand/ VC & 29 & 7,627 \\
\hline 5 & Midscale Chains & Fiesta Inn/ Fiesta Inn Loft & 75 & 10,392 \\
\hline 5 & Midscale Chains & Gamma by Fiesta Inn & 16 & 2,227 \\
\hline 6 & Economy Chains & One Hotels & 49 & 6,121 \\
\hline 6 & Economy Chains & Other & 2 & 413 \\
\hline
\end{tabular}

Source: Own elaboration with data from DATATUR and STR Global.

It is not mentioned what these „other" hotels are or their prices; therefore, it cannot make an accurate estimate. It is necessary to mention some key concepts to understand the table. Chain Scale refers to the name of ,classification" where the chain is located, that is, the Upper Up are chains that are expensive for a high income segment and hence the chain starts to fall down to level 6, which is the „Economy” that it can considered the most accessible among the hotels registered by stars among the corporate ones (STR Global, 2018). The Affiliation Name on the other hand refers to the specific name of the chain and what is the group to which it belongs, which for the purposes of the study the Posadas column was removed as the object of study.

According to the Posadas group report as of December 31, 2018 Posadas is the leading hotel operator in Mexico with 1,751 hotels and 27,491 owned, leased, franchised and managed rooms in the most important city and beach destinations visited in Mexico. 84\% of the rooms are located in city destinations and 16\% in beach destinations (Grupo Posadas, 2019).

\section{CONCLUSION}

Taking conducted analysis into account, the best feedback to confirm the hypothesis is that Posadas is the leader of the Mexican market thanks to its history, past and purchases of hotel sector strategies at the time. Thanks to this, it remains the market leader with the largest number of rooms and the largest number of hotels, since lodging services are substitute goods. Indeed, the price factor is what often determines the choice of the consumer before the substitute goods.

Taking into account the development of the document, it is necessary to develop strategies for future hosting times because there is not enough government support for tourism promotion, although it is true that these elements can be considered unfair since It gives more diffusion to the touristic pillars of the country that are already positioned, leaving disadvantaged other destinations not so favored by the field of tourism, but also not explored at all to generate tourism potential. Much remains in reflection if the occupation percentage is sufficiently determining for the tourist's consumption on the tourist site.

And also, the elements of innovation in lodging that threaten the occupancy percentages of a tourist site with traditional hotels such as the Airbnb. It is important to take into account that the figures for a percentage of occupancy are those registered in conventional hotels and not in digital platforms, which generates a bias of the true level of saturation of that destination. Posadas, for its part, is still working on the positioning of its hotels and its themes depending on the preferences and opportunities it has in terms of convenience, whether by location or area with the consumer. 


\section{REFERENCES}

Aristegui Noticias. (5 de Marzo de 2019). aristeguinoticias.com. Obtenido de De 20\%, la disminución en la derrama económica turística; "lo más complicado está por venir": Empresario: https://aristeguinoticias.com/0503/mexico/caida-del-turismo-en-mexico-es-un-asunto-de-inseguridad-lo-mas-complicado-esta-por-venir-apple-leisure-group/

DATATUR. (30 de marzo de 2019). Actividad hotelera. Obtenido de Porcentaje de ocupación: https://www.datatur.sectur.gob.mx:81/Reportes/Menu.aspx

Expansión. (20 de Marzo de 2019). Empresas. Obtenido de México se 'va de vacaciones' y cae en el ranking mundial de turismo: https:/expansion.mx/empresas/2019/03/20/mexico-seva-de-vacaciones-y-cae-en-el-ranking-mundial-de-turismo

Grupo Posadas. (21 de Febrero de 2019). Grupo Posadas - Finanzas. Obtenido de Resultados Operativos y Financieros: Cuarto Trimestre de 2018: http://cms.posadas.com/posadas/ Brands/Posadas/Region/Mexico/Hotels/Finanzas/Catalogs/Media/Reportes_trimestrales/ Espanol/Trimestres_2018/4T18.pdf

Grupo Posadas. (21 de Febrero de 2019). POSADAS. Obtenido de Nuestras marcas: http://www. posadas.com/nuestras-marcas

Parkin, M. (2010). Microeconomía. México: Pearson.

SECTUR. (Diciembre de 2018). DATATUR. Obtenido de Ranking Mundial del Turismo Internacional : https://www.datatur.sectur.gob.mx/SitePages/RankingOMT.aspx

STR Global. (20 de Diciembre de 2018). Documents. Obtenido de Chain Scales: https://www. strglobal.com/Media/Default/Documents/STR-ChainScales2018.xlsx 


\section{ANNEXES}

\section{Annex 1. Sum of the four companies}

The methodology used to obtain this concentration index was taken by the four strongest companies in the market in the field of hotels which are: Posadas, IHG, Marriot and Hilton.The concentration coefficient of the four companies is the percentage share of the four largest companies in the industry under study. A value of $0 \%$ denotes an industry with perfect competition, however, a value of $100 \%$ indicates a case of monopoly (Parkin, 2010).

Number of hotels of the four largest companies $=446$

Number of hotels of the rest of the companies $=226$

Total Hotels $=672$

$$
\text { Hotels }=\frac{4 \text { largest companies }}{\text { Total in the hotel industry }}(100)=\frac{446}{226}(100)=66.36 \%
$$

\section{Annex 2. The Herfindahl-Hirschman Index}

The IHH is calculated by adding the squares of the individual market participants for all the participants. Based on Parkin (2010) between lower value, the calculation of IHH we'll be talking about a more competitive market, if a market has an HHI greater than 1,800; we can conclude that we are talking about a non-competitive market (Parkin, 2010).

$$
\begin{aligned}
& I H H=\sum_{i=1}^{n} S_{i}^{2} \\
& I H H=26.19^{2}+20.68^{2}+11.30^{2}+8.18^{2}+7.44^{2}+6.10^{2}+5.50^{2}+3.72^{2}+2.52^{2}+2.38^{2}+2.38^{2}+1.78^{2}+1.78^{2} \\
& I H H=\mathbf{1 4 6 9 . 5 4}
\end{aligned}
$$

